\title{
Exploring the High Plains: Biodiversity, Geology, and Cultural Heritage through an Interdisciplinary Experiential Learning Experience for Honors Students
}

\author{
William Glider ${ }^{1}$, Leilani Arthurs ${ }^{2}$ and Jon Garbisch ${ }^{1}$ \\ ${ }^{1}$ University of Nebraska-Lincoln, School of Biological Sciences, Lincoln NE 68588 USA \\ ${ }^{2}$ University of Colorado Boulder, Department of Geological Sciences, Boulder CO 80309 USA \\ (wglider1@unl.edu; Leilani.Arthurs@colorado.edu)
}

\begin{abstract}
Partners in the Parks (PITP) is an outdoor experiential learning program coordinated by the National Collegiate Honors Council. PITP projects involve a partnership with any entity operated by the National Parks Service. These experiential excursions offer unique opportunities for collegiate honors students and faculty to visit areas of the American landscape noted for their beauty, significance and lasting value. Seven honors students from colleges, and universities around the nation participated in this one week excursion in June 2018. The following sites managed by the National Parks Service were visited: Niobrara Scenic River, Badlands National Park, Minuteman Missile National Historic Site, Mt. Rushmore National Memorial, Wind Cave National Park and Agate Fossil Beds National Monument. Students used photography and journaling to document their learning experience. The western High Plains is a unique region of mixed-grass, tall-grass, and sand hills prairie where six major ecosystems converge due to unique geology and geography, giving the region the name "biological crossroads." Faculty and park personnel provided onsite informal discussions and informational sessions which included historical, scientific, cultural, and other important areas unique to a given park. This project also provided the participants an excellent opportunity for students to learn about the cultural heritage of Lakota Indians (a First Nation of North America) and how this heritage was influenced by the natural history and geology of the region as well as US governmental policies. An afternoon was spent at the Oglala Lakota College where faculty and staff served the students a traditional Lakota meal and gave short presentations on diverse topics such as medicinal plants used by the Lakota and a research project on growing mushrooms as a cash crop. The excursion also took advantage of exciting recreational opportunities in the parks to broaden participant's understanding of the overall value of national parks to our country and its citizens. This included hiking in the Badlands, participation in the Wild Cave Tour at Wind Cave and kayaking the Niobrara River.
\end{abstract}

Keywords: interdisciplinary, Honors field experience, experiential learning, Partners in the Parks, National Park Service, High Plains

Link to Original Poster File: https://doi.org/10.37590/able.v41.poster69

\section{Mission, Review Process \& Disclaimer}

The Association for Biology Laboratory Education (ABLE) was founded in 1979 to promote information exchange among university and college educators actively concerned with teaching biology in a laboratory setting. The focus of ABLE is to improve the undergraduate biology laboratory experience by promoting the development and dissemination of interesting, innovative, and reliable laboratory exercises. For more information about ABLE, please visit http://www.ableweb.org/.

Advances in Biology Laboratory Education is the peer-reviewed publication of the conference of the Association for Biology Laboratory Education. Published articles and extended abstracts are evaluated and selected by a committee prior to presentation at the conference, peer-reviewed by participants at the conference, and edited by members of the ABLE Editorial Board. Published abstracts are evaluated and selected by a committee prior to presentation at the conference. 


\section{Citing This Article}

Glider W, Arthurs L, Garbisch J. 2020. Exploring the high plains: biodiversity, geology, and cultural heritage through an interdisciplinary experiential learning experience for honors students. Article 69 In: McMahon K, editor. Advances in biology laboratory education. Volume 41. Publication of the 41st Conference of the Association for Biology Laboratory Education (ABLE). https://doi.org/10.37590/able.v41.abs69

Compilation (C) 2020 by the Association for Biology Laboratory Education, ISBN 1-890444-17-0. All rights reserved. No part of this publication may be reproduced, stored in a retrieval system, or transmitted, in any form or by any means, electronic, mechanical, photocopying, recording, or otherwise, without the prior written permission of the copyright owner.

ABLE strongly encourages individuals to use the exercises in this volume in their teaching program. If this exercise is used solely at one's own institution with no intent for profit, it is excluded from the preceding copyright restriction, unless otherwise noted on the copyright notice of the individual chapter in this volume. Proper credit to this publication must be included in your laboratory outline for each use; a sample citation is given above. 